\title{
ANALISIS KEGIATAN EKSPOR KOPI ANTARA KUALITAS DENGAN HARGA DALAM PERSPEKTIF AKAD BAI' AS-SALAM
}

\author{
Ikram Pratama ${ }^{1}$, Hardi Alunaza $^{2}$, Arifin Abdullah ${ }^{3}$, Muhammad Iqbal ${ }^{4}$ \\ ${ }^{134}$ Prodi Hukum Ekonomi Syariah UIN Ar-Raniry Banda Aceh \\ ${ }^{2}$ Prodi Hubungan Internasional FISIP Universitas Tanjungpura \\ Ikrampratama822@gmail.com
}

\begin{abstract}
Abstrak
Kegiatan ekspor kopi adalah salah satu bentuk dari pertukaran barang dan jasa yang melewati batas kepabeanan negara. Kegiatan ekspor ini terjadi akibat kebutuhan yang tidak bisa dipenuhi di dalam negeri, sehingga harus diperoleh dari negara lain. Kegiatan ini diawali dengan proses negosiasi yang diteruskan dalam kesepakatan. Hal yang menjadi permasalahan dalam penelitian ini adalah Bagaimana bentuk klausula kontrak perjanjian ekspor kopi berdasarkan perspektif akad Bai' As-Salam terhadap kontrak ekspor kopi antara kualitas dan harga. Tulisan ini menggunakan metode empiris dengan pendekatan yuridis formal dan normatif fiqh muammalah dengan jenis penelitian deskriptif. Teknik pengumpulan data dilakukan dengan cara wawancara dan studi pustaka. Hasil dari penelitian ini memperlihatkan bentuk kontrak perjanjian ekspor produk kopi dilakukan dalam perjanjian baku dengan seller untuk meminimalkan risiko. Prakteknya jika seller melakukan kesalahan saat mengirimkan barang pesanan maka seller bertanggung jawab atas kerugian tersebut. Dalam menganalisis sistem pengalihan risiko akad Ba'i as-Salam dalam transaksi ekspor kopi, jika rukun dan syarat tersebut dapat dilaksanakan sepenuhnya maka kegiatan ekspor yang di lakukan oleh penjual diperbolehkan, meskipun tidak disebutkan dalam hukum Syariah, tetapi dalam transaksi Sudah tersirat, yaitu kepercayaan, persetujuan dan kerelaan.
\end{abstract}

Kata Kunci: Ekspor Kopi, Kualitas dan Harga, Ba'I As-Salam.

\section{PENDAHULUAN}

Kegiatan ekspor dan impor yang sering terjadi merupakan salah satu bentuk pertukaran dari barang dan jasa yang tentu melewati batas kepabeanan negara. Hal ini terjadi karena adanya kebutuhan yang belum terpenuhi di tingkat nasional sehingga membutuhkan bantuan dari negara lain. Meski harus diakui bahwa perdagangan lintas batas negara berbeda dengan kegiatan perdagangan yang terjadi di dalam negeri. Hal ini ditandai dengan hadirnya banyak perbedaan antara kedua negara dari mana para pelaku kegiatan perdagangan berasal. Misalnya seperti perbedaan yang terdapat dalam peraturan kepabeanan, perbedaan terkait standar mutu produk,

Al Qalam: Jurnal Ilmiah Keagamaan dan Kemasyarakatan Vol. 16, No. 2

Maret - April 2022 
Ikram Pratama, Hardi Alunaza, Arifin Abdullah, Muhammad Iqbal : Analisis Kegiatan Ekspor Kopi Antara Kualitas Dengan Harga Dalam Perspektif Akad Bai’ As-Salam

perbedaan mengenai standar ukuran dan takaran timbangan serta terkait peraturan perdagangan luar negeri yang ditetapkan oleh pemerintah di Indonesia ${ }^{1}$. Seperti diketahui bersama bahwa setiap kegiatan perdagangan internasional harus berbentuk kesepakatan dalam prosesnya.

Merujuk pada konsep ulama fiqih, proses jual beli harus selalu dikemas dalam bentuk kerangka formalistik hukum. Jual beli juga harus selalu dikemas dan memperhatikan adanya proses akad. Serta jual beli juga dirumuskan dalam tatanan syarat, termasuk rukun, pengakuan sah, batal, hak serta kewajiban dalam prosesnya. Jika memperhatikan panduan Islam dalam jual beli, ada model jual beli yang masuk dalam kategori dilarang dan ada jual beli yang diperkenankan. Konsep dalam jual beli fiqih merujuk kepada pedoman dari tuntunan hidup yakni Al-Qur'an dan hadist. Termasuk menerima dinamika baru yang dapat ditemui di tengah-tengah masyarakat. $^{2}$

Konsep "Bai' As-Salam" yang dikenal dalam proses dan transaksi jual beli merupakan pendapat dari beberapa ahli hukum Fiqih seperti Imam Malik dan Imam Syafi'I yakni terkait penetapan periode minimum sebagai syarat dari sahnya proses jual beli. Dalam prakteknya, masyarakat sering kali memesan barang yang cukup jauh jarak tempuhnya. Dalam konsep Bai' As-Salam adalah penekanan terkait pembayaran yang dilaksanakan terlebih dahulu dan barangnya diserahkan pada beberapa periode berikutnya. Dalam pandangan Islam, konsep ini merupakan salah satu solusi yang tepat yang dapat diimplementasikan dengan tujuan agar dapat menghindari adanya riba. ${ }^{3}$

Secara fiqhiyyah, dalam fiqh muamalah kualitas dari suatu produk yang menjadi objek transaksi sangat penting diketahui dengan baik oleh para pihak, bahkan menjadi syarat dari objek transaksi (mabi'). Sebagai syarat transaksi, kualitas produk ini mempengaruhi keabsahan akad yang di polarisasi sebagai syarat objek akad, yang memiliki banyak perspektif di kalangan fuqaha.

Fukaha telah menyatukan suara bahwa konsep jual beli yang ditawarkan ini dapat dilakukan oleh setiap orang pada setiap barang yang sudah ditakar. Serta adanya larangan terhadap barang yang tidak berada dalam tanggungan yakni berupa rumah dan tanah. Terdapat juga perselisihan antara ulama terkait barang lain seperti barangan dagangan berupa hewan.

Para Imam Mazhab berbeda pendapat tentang jual beli secara salam pada barang-barang yang dapat dihitung, tetapi satuannya dapat berlebih dan berkurang keadaannya, seperti buah delima dan semangka. Hanafi berpendapat tidak boleh salam padanya, baik secara ditimbang

\footnotetext{
${ }^{1}$ Amir M.S, Ekspor Impor Teori dan Penerapan, (Jakarta: PT.Pustaka Binaan Pressindo, Jakarta, 1999, hlm. 22

2 Tsalabi, Muhammad Mustofa, 1964, al-Madkhal Fi Ta'rif al-Fiqh al-Islam Wa Qawa'id al Milkiyyah Wa al-Uqudiyyah, Mathba"eah Dar al-Ta"'rif. H.508 h. 108 .

3 Muhammad Syafi'i Antonio, Bank Syari'ah dari Teori ke Praktik, (Jakarta: Gema Insani 2007),
}

Al Qalam: Jurnal Ilmiah Keagamaan dan Kemasyarakatan Vol. 16, No. 2 Maret - April 2022 
Ikram Pratama, Hardi Alunaza, Arifin Abdullah, Muhammad Iqbal : Analisis Kegiatan Ekspor Kopi Antara Kualitas Dengan Harga Dalam Perspektif Akad Bai’ As-Salam

maupun dihitung. Maliki berpendapat boleh secara mutlak. Syafi'i, boleh dengan cara ditimbang. Sedangkan dari Hambali boleh dengan cara dihitung secara mutlak. ${ }^{4}$

Jual beli salam merupakan jenis akad jual beli barang dengan kriteria tertentu dengan pembayaran tunai. Sehingga menjadi sebuah keharusan, barang yang dipesan adalah barang yang dapat ditentukan kriterianya dengan jelas, seperti jenis, ukuran, berat, takaran dan lain sebagainya. Penyebutan kriteria ini bertujuan untuk menentukan barang yang diinginkan oleh kedua belah pihak dan menghindarkan sengketa.

Dengan demikian, secara umum obyek salam sebagaimana yang telah dijelaskan di atas dapat disimpulkan, yaitu benda-benda yang dapat dihitung jumlahnya, benda-benda yang dapat diketahui jenisnya dan benda-benda yang dapat ditimbang beratnya. Maka itulah yang bisa dijadikan sebagai objek salam. Objek akad (ma'qud alaihi) merupakan syarat sah terjadinya sebuah akad dalam jual beli. Di dalam objek akad juga terdapat syarat yang menentukan keabsahan akad jual beli

Dalam memberikan kriteria masuk dalam syarat ini perlu diperhatikan bahwa masalah kriteria ini akan berbeda dari zaman ke zaman. Sehingga tidak semua yang disampaikan para ulama ahli fiqih zaman dulu sebagai kriteria barang yang tidak bisa diberikan kriteria jelas itu pasti benar, sebab dengan perkembangan teknologi dan pengetahuan muncul alat yang dapat mendeteksi kriteria dengan jelas sehingga dapat diserahkan sesuai dengan kriteria yang disepakati ketika akad.

Dalam transaksi jual beli kopi dengan pihak distributor mancanegara, pihak produsen harus mampu menghadirkan objek transaksi bisnisnya dengan baik. Hal ini penting dilakukan untuk memastikan konsumen nya akan membeli produk yang dihasilkannya dalam jangka panjang dan dalam jumlah skala besar. Untuk kerja sama jual beli dengan pihak mancanegara, transaksi bisnis ini cenderung dijalankan dalam jangka waktu yang lama.

Dalam tahap negosiasi terdapat aspek utama yang harus ditetapkan. Isi negosiasi meliputi jenis kopi yang akan di ekspor kemudian penentuan kualitas produk berdasarkan hasil uji standar dan penentuan kuantitas yang akan dikirim. Metode pengiriman dipilih oleh importir dan disesuaikan dengan distributor yang tersedia dan juga biaya berdasarkan jarak tujuan ekspedisi. Setelah mencapai kesepakatan maka akan dilakukan penandatanganan kontrak. Setelah kontrak selesai akan dilanjutkan ke tahap pembayaran. Sistem pembayaran akan dilakukan sesuai dengan hasil kesepakatan, pada umumnya akan dilakukan pembayaran di muka dan pembayaran berikutnya setelah barang dikirimkan.

4 Al-'Allamah Muhammad bin 'Abdurrahman ad-Dimasyqi, Fiqih Empat Mazhab Bandung: Hasyimi Press, 2001), hlm. 246.

Al Qalam: Jurnal Ilmiah Keagamaan dan Kemasyarakatan Vol. 16, No. 2

Maret - April 2022 
Ikram Pratama, Hardi Alunaza, Arifin Abdullah, Muhammad Iqbal : Analisis Kegiatan Ekspor Kopi Antara Kualitas Dengan Harga Dalam Perspektif Akad Bai’ As-Salam

Dalam beberapa kasus yang muncul pada transaksi jual beli kopi secara order yang dilakukan oleh pihak pembeli dari pihak mancanegara dan pihak importir dari Aceh Tengah adalah kemampuan pihak importir dalam menyediakan stok yang di butuhkan oleh pihak importir sesuai dengan spesifikasi yang di tetapkan karena stok ini membutuhkan konsistensi dari pihak importir untuk mempertahankan kualitas yang disepakati dan ditetapkan dalam kontrak.

Konsistensi kualitas biji kopi yang dipesan oleh pihak pembeli dari lokal dan manca negara baik dalam bentuk partai besar maupun partai kecil pada hakikatnya sangat penting, karena hal ini menyangkut dengan komitmen bisnis untuk menjaga kesetiaan konsumen nya agar tetap menjadi pembeli yang setia. Namun hal ini selalu menjadi kendala yang harus dicari solusi oleh pihak pedagang. Oleh karena itu pihak pembeli sering kecewa dengan transaksi bisnis ini karena harus mengolah lagi agar kualitasnya baik terutama pada kadar air dan juga tingkat kematangan biji kopi.

Beberapa persoalan krusial yang terjadi pada transaksi jual beli orderan ini hampir tidak mungkin dihindari mulai dari persoalan kualitas produk, perbedaan harga aktual di pasar dunia ketika biji kopi dikirim, masa pengiriman, termasuk masa muat dan masa bongkar produk setelah pengiriman dilakukan, karena hal ini biasanya membutuhkan cost yang menimbulkan dilema di antara para pihak untuk menanggung beban cost yang muncul.

Untuk permasalahan yang terjadi dalam orderan trading kopi ini, membutuhkan sebuah kepastian hukum yang harus dicantumkan secara pasti dalam kontrak supaya tidak menimbukan kerugian bagi para pihak. Dalam diskursus Bai' As-Salam memang tidak mencantumkan syarat yang spesifik untuk setiap transaksi. Ketentuan umum yang ditetapkan memudahkan bagi para pihak untuk membuat klausula perjanjian, sehingga lebih fleksibel. Dari permasalahan di atas penulis tertarik untuk meneliti permasalahan untuk makalah dengan judul "analisis kegiatan ekspor kopi antara kualitas dengan harga dalam perspektif Akad Bai' As-Salam".

\section{METODOLOGI PENELITIAN}

Penelitian ini adalah riset kualitatif deskriptif. Teknik pengumpulan data dalam tulisan ini adalah dengan observasi, dokumentasi, wawancara serta didukung dengan studi kepustakaan berupa buku, jurnal, laporan penelitian dan sumber dari media online yang realible untuk dapat mendukung hasil akhir dari tulisan ini sehingga sesuai dengan hipotesis dari penulis. Adapun teknik analisa data adalah bersumber dari Miles Huberman yakni pengumpulan data, pemilahan data, dan proses penarikan kesimpulan.

Al Qalam: Jurnal Ilmiah Keagamaan dan Kemasyarakatan Vol. 16, No. 2

Maret - April 2022 
Ikram Pratama, Hardi Alunaza, Arifin Abdullah, Muhammad Iqbal : Analisis Kegiatan Ekspor Kopi Antara Kualitas Dengan Harga Dalam Perspektif Akad Bai’ As-Salam

\section{HASIL DAN PEMBAHASAN}

\section{Rukun dan Syarat Bai' As-Salam}

Rukun dan syarat merupakan hal yang harus terpenuhi dalam suatu perjanjian. Secara bahasa, rukun adalah "yang harus dipenuhi untuk sahnya suatu pekerjaan," sedangkan syarat adalah "ketentuan, peraturan, petunjuk) yang harus diindahkan dan dilakukan." Rukun dan syarat, dalam syariah, sama-sama menentukan sah atau tidaknya suatu transaksi. Sedangkan dalam Ensiklopedi Hukum Islam, didefinisikan, rukun adalah "suatu unsur yang yang merupakan bagian tak terpisahkan dari suatu perbuatan atau lembaga yang menentukan sah atau tidaknya perbuatan tersebut dan ada atau tidak adanya sesuatu itu." Definisi syarat adalah "sesuatu yang tergantung padanya keberadaan hukum syar'i dan ia berada di luar hukum itu sendiri." 5

Rukun dan syarat salam pada dasarnya sama dengan jual beli, yakni dengan ijab dan kabul menurut Hanafiyah, sedangkan menurut ulama selain Hanafiyah rukun akad salam ada tiga, yaitu muslam dan muslam ilaih (pemesan dan penjual), ra'sul mal, salan, muslam fih, (harga pokok, dan harga pesanan), shigat (ijab dan kabul).

\section{a. Rukun Salam}

Rukun salam menurut Hanafiah adalah ijab dan qabul. Sedangkan menurut jumhur ulama, seperti halnya jual beli, rukun salam itu meliputi:

a. Aqid, yaitu pembeli atau al-muslim atau rabbussalam, dan penjual atau al-muslam ilaih.

b. Ma'qud 'alaih, yaitu muslam fih (barang yang dipesan), dan harga atau modal salam (ra's al-mal as-salam).

c. Shigat yaitu ijab dan qabul. ${ }^{6}$

b. Syarat-syarat Salam

Pada Bai' As-Salam, di samping harus terpenuhi syarat-syarat jual beli biasa, seperti pihak yang melakukan akad cakap hukum, barang yang ada dalam transaksi merupakan barang yang halal, ada secara hakiki, dan dapat diserah terimakan. Sedangkan untuk sahnya para ulama sepakat harus memenuhi syarat-syarat sebagai berikut:

a. Ra'sul mal (harga asal)

1. Diketahui jumlahnya.

2. Jelas jenisnya (misal dinar atau dolar ataupun rupiah).

3. Merupakan uang yang sah.

4. Diserahkan pada waktu akad baik tunai maupun cek sebelum para pihak berpisah dari tempat akad.

\footnotetext{
${ }^{5}$ Ramli, Semmawi. Urgensi Akad Dalam Hukum Ekonomi Islam, Jurnal Al-Syir'ah Vol. 8, No. 2, 2010, hlm. 507

${ }^{6}$ Wahbah Zuhaili, al-Fiqh al-Islami wa Adillatuh,( Jakarta : Gema Insani, 2011), hlm. 599.
}

Al Qalam: Jurnal Ilmiah Keagamaan dan Kemasyarakatan Vol. 16, No. 2

Maret - April 2022 
Ikram Pratama, Hardi Alunaza, Arifin Abdullah, Muhammad Iqbal : Analisis Kegiatan Ekspor Kopi Antara Kualitas Dengan Harga Dalam Perspektif Akad Bai’ As-Salam

Jika uang diserahkan setelah pihak yang melakukan transaksi berpisah dari tempat, maka akad salam menjadi batal. Karena yang dimaksud dengan akad salam, adalah mendahulukan menyerahkan uang (uang di muka). Dalam akad salam, barang adalah hutang yang berada dalam tanggungan. Apabila pembayaran dilakukan setelah akad maka akan memunculkan jual beli hutang dengan hutang.

b. Muslam fih (barang), disyaratkan ${ }^{7}$ :

1. Barang yang dipesan merupakan barang yang dapat diketahui kriteria dan spesifikasi yang membedakan dengan barang yang lain.

2. Pembeli menyebutkan sifat atau kriteria barang meliputi jenis, macam, dan kualitas.

3. Diketahui ukuran baik melalui takaran, timbangan, hitungan, atau jumlahnya.

4. Jelas batas waktu dan tempat penyerahan barang.

5. Jenis barang dan kriterianya merupakan barang yang ada di pasaran

6. Akad bersifat tetap, tidak ada khiyar syarat bagi kedua belah pihak atau salah seorang dari keduanya.

7. Barang yang dipesan merupakan hutang dan menjadi tanggungan penjual.

8. Tidak menimbulkan riba fadhl.

Kegiatan Ekspor Kopi Antara Kualitas Dengan Harga dalam Perspektif Akad Bai' AsSalam

Klausula merupakan komponen penting yang harus dimiliki dalam setiap perjanjian yang dilaksanakan baik antara dua pihak maupun lebih. Klausula perjanjian yang dibuat tersebut bila dilakukan secara otentik akan memiliki kekuatan hukum tetap dan memberi efek hukum terhadap kedua belah pihak. Pembuatan klausula dalam suatu perjanjian dicantumkan demi mengantisipasi terjadinya wanprestasi. ${ }^{8}$

Adapun bentuk perjanjian yang dilakukan antara pihak importir dan eksportir dilakukan dalam bentuk kontrak lisan yang harus disetujui oleh kedua belah pihak sebelum pihak eksportir melakukan pekerjaanya sebagai seller untuk menjual produk kopi ekspor yang akan dikirimkan kepada buyer. Kontrak perjanjian yang dibuat bisa saja dalam bentuk lisan, sehingga klausula perjanjian yang dibuat oleh pihak eksportir hanya sebatas pemahaman terhadap kewajibankewajiban yang harus dilakukan dalam pemasaran dan juga hak-hak yang akan diperoleh setelah kewajiban pengiriman dilakukan secara tuntas. Pada objek penelitian yang penulis lakukan, pihak manajemen eksportir seperti CV. Oro Coffee seluruh kontraknya dibuat secara tertulis dan juga berlaku pada saat lisan.

${ }^{7}$ Rozalinda, Fiqh Ekonomi Syariah, (jakarta: PT Raja Grafindo Persada, 2016), hlm. 95-97

${ }^{8}$ Sri Rejeki Hartono, Paramita Prananingtyas dan Fahimah, Kamus Hukum Ekonomi, 2010: 87

Al Qalam: Jurnal Ilmiah Keagamaan dan Kemasyarakatan Vol. 16, No. 2 Maret - April 2022 
Ikram Pratama, Hardi Alunaza, Arifin Abdullah, Muhammad Iqbal : Analisis Kegiatan Ekspor Kopi Antara Kualitas Dengan Harga Dalam Perspektif Akad Bai’ As-Salam

CV. Oro Coffee head office dan kantor operasionalnya terletak di Mongal Kecamatan Bebesen Takengon Aceh Tengah. Wilayah tujuan ekspor kopi CV. Oro Coffee ini mencakup ke negara-negara anggota MEE (Masyarakat Ekonomi Eropa), negara kawasan Amerika khususnya negara Amerika Serikat serta negara di kawasan Asia seperti Jepang, Singapura, Korea dan Malaysia (Asosiasi Eksportir Kopi Indonesia (AEKI, 2005). Perusahaan ini telah memiliki badan hukum sehingga secara legalitas dan manajemen telah memiliki posisi yang kuat sehingga pada pembuatan kontraknya telah memiliki kontrak baku, dan mengikat pihak importir dan eksportir yang memiliki hubungan sepenuhnya harus mengikuti ketentuan isi kontrak yang telah dibuat oleh CV. Oro Coffee tersebut.

Dalam transaksi pihak pembeli maupun pihak penjual harus mematuhi klausula dalam pembuatan kontrak yang bertujuan untuk memperjelas ketentuan hak dan kewajiban bagi kedua belah pihak baik dari penjual selaku eksportir dan juga pembeli selaku importir. Dalam hal ini pihak CV. Oro Coffee menyusun bentuk klausula pemesanan produk berdasarkan ketentuan umum dari Menteri Perdagangan Republik Indonesia. Klausula ini dibagi ke dalam dua bagian dimana pada bagian pertama menetapkan ketentuan-ketentuan dan istilah yang perlu diketahui sebelum melakukan kegiatan ekspor. Kemudian dilanjutkan di bagian kedua dimana akan dijelaskan ketentuan yang harus dilakukan baik dari calon pembeli dan juga CV. Oro Coffee. Ada pun bentuk klausula yang harus disepakati oleh pihak pembeli (importir) dalam pemesanan (eksportir) adalah sebagai berikut:

Pasal 1 posisi para pihak

(1) Pihak pertama selanjutnya disebut Seller dalam hal ini adalah CV. Oro Coffee

(2) Pihak kedua selanjutnya disebut buyer dalam hal ini individu maupun kelompok internasional sebagai calon pembeli produk

(3) Ekspedisi Muatan Kapal Laut (EMKL) sebagai badan usaha berizin negara yang mengurus dokumen dan muatan yang akan diangkut melalui kapal dalam jumlah/muatan besar.

(4) Kopi adalah kopi yang termasuk dalam Pos tarif/HS 09.01 dan 21.01

Pasal 2 pelaksanaan pekerjaan

Buyer melakukan perjanjian jual beli baik secara lisan maupun tulisan kepada pihak CV. Oro Coffee

Pasal 3 produk yang dijual

Pihak pertama (Seller) dalam hal ini yaitu pihak CV. Oro Coffee menyediakan kopi dengan jenis arabika grade 1 untuk dijual kepada pihak kedua yaitu pembeli (buyer).

Pada perjanjian di atas pada Pasal 1 pihak CV. Oro Coffee merupakan perusahaan yang melakukan kegiatan ekspor sebagai seller non retail dan menjual produk kopi kepada pihak

Al Qalam: Jurnal Ilmiah Keagamaan dan Kemasyarakatan Vol. 16, No. 2

Maret - April 2022 
Ikram Pratama, Hardi Alunaza, Arifin Abdullah, Muhammad Iqbal : Analisis Kegiatan Ekspor Kopi Antara Kualitas Dengan Harga Dalam Perspektif Akad Bai’ As-Salam

buyer. CV. Oro Coffee kini melakukan produksi dan juga ekspor kopi specialty dengan jenis kopi Arabica grade 1 yang berlokasi di Mongal Kecamatan Bebesen Kabupaten Aceh Tengah Provinsi Aceh. Buyer yang disebutkan pada pasal 1 ayat (2) adalah kelompok maupun perorangan yang akan melakukan perjanjian jual beli kopi specialty dengan permintaan jenis kopi yang terdapat dalam peraturan Menteri Perdagangan Republik Indonesia kepada pihak CV. Oro Coffee.

Ekspedisi Muatan Kapal Laut (EMKL) adalah perusahaan jasa bidang logistik jalur laut yang sudah memiliki izin dari pemerintah Indonesia untuk melakukan ekspedisi secara internasional dan dalam skala yang besar dan berat menggunakan kapal laut. Pihak EMKL bertugas menyimpan dokumen Pemberitahuan Ekspor Barang (PEB) dan juga melakukan ekspedisi.

Pada pasal satu juga disebutkan jenis kopi yang diekspor keluar negeri sebagaimana disebutkan dalam peraturan Menteri Perdagangan Republik Indonesia Nomor 80 Tahun 2019. Dalam pasal 1 ayat (3) disebutkan bahwa jenis kopi yang dimaksud adalah sebagai berikut:

Selanjutnya pada pasal 2 dijelaskan bahwa untuk memulai sebuah perjanjian jual beli kopi ekspor pihak buyer harus terlebih dahulu menghubungi pihak CV. Oro Coffee baik secara langsung maupun melalui pesanan secara online melalui email. Hal ini berdasarkan kedudukan $\mathrm{CV}$. Oro Coffee sebagai perusahaan non retail di bawah organisasi internasional.

CV. Oro Coffee menjual kopi dengan jenis arabika grade 1 sebagaimana disebutkan dalam pasal 3 maka dengan ini pihak buyer hanya akan membeli kopi dengan jenis tersebut. Selanjutnya seller juga hanya akan menjual produk sesuai jenis kopi tersebut sehingga tidak terjadi kekeliruan dalam menentukan jenis kopi yang akan di jual belikan. Hal ini bertujuan untuk menjaga kualitas kopi yang akan di ekspor dimana kopi yang dikirim oleh pihak CV. Oro Coffee hanyalah kopi dengan kualitas terbaik.

Setelah semua perjanjian dalam bentuk kejelasan posisi dan juga spesifikasi sudah selesai maka tahap selanjutnya adalah pembuatan perjanjian dalam bentuk kewajiban masing-masing pihak. Dalam ketentuan selanjutnya akan ditetapkan beberapa hal seperti negara tujuan, metode pembayaran sampai dengan jadwal pengiriman seperti yang tertera berikut:

\section{Pasal 4 kewajiban buyer}

\section{(1) Pihak Buyer menentukan negara tujuan pengiriman}

(2) Pihak Buyer harus memilih metode pembayaran internasional baik secara tunai/kontan dan juga metode pembayaran internasional lain diantaranya, Telegrafik transfer, wesel, letter of credit, dan cek.

Al Qalam: Jurnal Ilmiah Keagamaan dan Kemasyarakatan Vol. 16, No. 2

Maret - April 2022 
Ikram Pratama, Hardi Alunaza, Arifin Abdullah, Muhammad Iqbal : Analisis Kegiatan Ekspor Kopi Antara Kualitas Dengan Harga Dalam Perspektif Akad Bai’ As-Salam

(3) Pihak Buyer melakukan negosiasi dengan pihak seller dalam Menentukan jadwal ekspor termasuk didalamnya sanksi dan denda apabila terjadi kesalahan atau wanprestasi dari setiap pihak.

Pasal 5 kewajiban Seller

(1) Memiliki dokumen penyerta ekspor kopi ( Surat Keterangan Asal) Form ICO

(2) Membuat packing list, invoice, shipping instruction, dan SPEK

Pada pasal 4 dinyatakan bahwa buyer harus menentukan negara tujuan pengiriman produk ekspor yang kemudian akan dikirim oleh seller. Hal ini perlu dilakukan agar dapat menentukan jalur pengiriman dan juga biaya pengiriman. Kemudian sebagaimana disebutkan di dalam klausula perjanjian pada pasal 4 ayat (2) buyer akan menentukan metode pembayaran yang disebutkan untuk mencapai kesepakatan bisnis. Di antaranya adalah tunai atau metode non tunai seperti berikut:

a. Telegrafik Transfer

Telegrafik transfer adalah sistem pembayaran yang dilakukan dengan menggunakan cek yang diteruskan oleh telegram. Sistem pembayaran ini akan dilakukan oleh bank dalam negeri kepada pelanggan luar negeri. Untuk dapat melakukan pembayaran dengan cara ini, sumber dana yang digunakan oleh bank adalah sumber dana dari rekening pihak yang akan membayar. Sistem pada metode pembayaran ini dengan cara mencatat jumlah valuta pada rekening bank cabang oleh bank pemberi kredit.

b. Wesel

Metode pembayaran internasional ini dapat dilakukan oleh bank dengan kesepakatan antara pihak penjual dan pembeli dari perjanjian sebelumnya. Dengan menggunakan wesel, dapat diartikan pihak bank dalam negeri akan mengeluarkan surat perintah pembayaran kepada bank di luar negeri sesuai dengan tujuan, jumlah nominal uang, dan identitas yang tertulis dalam wesel.

c. Letter of Credit $(L / C)$

Letter of credit $(L / C)$ adalah institusi berupa jaminan yang diterbitkan oleh bank atas dasar permintaan nasabahnya (aplikant) untuk membayar sejumlah uang kepada penerima $L / C$ (beneficiary) atas penyerahan seperangkat dokumen sesuai dengan syarat dan kondisi yang diminta dalam $L / C$. Letter of credit $(L / C)$ merupakan fasilitas atau jasa untuk memperlancar transaksi jual beli barang yang dimiliki oleh bank sebagai jaminan antar pihak yang menjual dan juga membeli, dengan tujuan memberikan rasa percaya kepada masing-masing pihak yang melakukan transaksi. Apabila eksportir dan importir kurang mengetahui dan memahami

Al Qalam: Jurnal Ilmiah Keagamaan dan Kemasyarakatan Vol. 16, No. 2

Maret - April 2022 
Ikram Pratama, Hardi Alunaza, Arifin Abdullah, Muhammad Iqbal : Analisis Kegiatan Ekspor Kopi Antara Kualitas Dengan Harga Dalam Perspektif Akad Bai’ As-Salam

proses aplikasi pembukaan Letter of Credit, maka dapat dipastikan bahwa akan terjadi kesalahpahaman yang dapat menghambat proses transaksi internasional.

\section{Perspektif Akad Bai' As-Salam terhadap kontrak ekspor kopi antara kualitas dan harga.}

Kriteria produk kopi ekspor yang ditawarkan mengikuti ketentuan yang telah ditentukan oleh Menteri Perdagangan Republik Indonesia. Selain ketentuan dalam negeri pada kegiatan ekspor kopi di CV. Oro Coffee juga mengikuti ketentuan lembaga International Coffee Organization (ICO). Cv.Oro Coffee sebagai anggota ICO dan juga perusahaan non retail harus mengikuti seluruh ketentuan ekspor baik sesuai ketentuan pemerintah maupun lembaga yang menaunginya. Hal Ini bertujuan sebagai bentuk kerja sama Cv.Oro Coffee dengan lembaga internasional dalam melakukan bisnis ekspor ini dimana pihak ICO akan memberikan akses ke pasar kopi internasional untuk kemudian CV. Oro Coffee bisa menjual produk mereka.

CV. Oro Coffee dalam praktek kontrak nya memiliki sistem penyortiran yang ketat dimana biji kopi dipilih dengan teknik triple handed yang bertujuan untuk menjaga kualitas biji kopi. Teknik penyortiran ini dilakukan oleh para pekerja dan dilakukan dengan cara memilih langsung biji kopi berdasarkan bentuk, ukuran, dan kecacatan pada biji kopi. kegiatan ini disebut sebagai quality control dimana kegiatan ini sangat penting dilakukan untuk meminimalisir kesalahan pada pengiriman kopi ekspor.

CV. Oro Coffee menggunakan penentuan mutu kopi berdasarkan sistem nilai cacat (defects value system) sesuai keputusan ICO. Dalam sistem ini biji kopi dinilai berdasarkan tingkat kecacatan bijinya, semakin banyak nilai cacatnya, maka kualitas kopi akan semakin rendah dan sebaliknya.

Dalam kontrak oleh pihak CV. Oro Coffee dengan pihak buyer dalam transaksi ekspor kopi, pihak CV. Oro Coffee akan membuat klausula dimana di dalamnya terdapat diktum yang menyebutkan jenis kopi yang akan diekspor yaitu arabika grade 1. Selanjutnya buyer akan menentukan apakah akan membeli produk tersebut atau tidak atas dasar diktum yang telah disebutkan dalam kontrak perjanjian. Buyer bebas memilih untuk melanjutkan perjanjian atau membatalkan perjanjian di dalam tahapan menentukan jenis kopi. Setelah dilakukan persetujuan maka akan dilanjutkan proses pengiriman oleh pihak CV. Oro Coffee.

Dalam menangani pertanggungan apabila terjadi kesalahan pihak CV. Oro Coffee tidak mencantumkan di kontrak perjanjian melainkan ketentuan tersebut sudah masuk ke dalam kesepakatan yang dilakukan para pihak pada saat proses negosiasi seperti yang tertera pada pasal 4 ayat (3) dalam klausula kontrak Cv.Oro Coffee.

Dalam kegiatan ekspor kopi pihak CV. Oro Coffee hanya akan menerima pertanggungan apabila terjadi kesalahan yang disebabkan pada saat proses penentuan standar (quality control)

Al Qalam: Jurnal Ilmiah Keagamaan dan Kemasyarakatan Vol. 16, No. 2

Maret - April 2022 
Ikram Pratama, Hardi Alunaza, Arifin Abdullah, Muhammad Iqbal : Analisis Kegiatan Ekspor Kopi Antara Kualitas Dengan Harga Dalam Perspektif Akad Bai’ As-Salam

sampai dengan penyerahan produk ekspor kepada pihak yang melakukan shipping. Pada tahapan ini apabila terjadi wanprestasi atau galat yang terjadi dalam proses seperti yang penulis sebut sebelumnya yang dilakukan oleh pihak CV. Oro Coffee maka eksportir akan dikenakan sanksi berupa denda dengan nilai kontrak yang telah disepakati dan mendapat penalti selama 5 tahun tidak dapat melakukan kegiatan ekspor.

Selanjutnya apabila terjadi wanprestasi pihak CV. Oro Coffee akan melakukan evaluasi terhadap standar kopi yang akan dikirim berikutnya. Eksportir akan mengoreksi setiap bagian dari kegiatan quality control dalam perusahaan agar penetapan kualitas dapat sesuai dengan permintaan buyer.

Sistem kontrak pada kegiatan ekspor mendapat perhatian dikarenakan kontrak pada ekspor sangat penting untuk dilakukan, berdasarkan tujuan keamanan bagi kedua belah pihak baik seller dan juga pihak buyer. Sifat kontrak yang mengikat memiliki kekuatan hukum yang mampu melindungi hak dan kewajiban para pihak yang melakukan perjanjian sehingga kegiatan transaksi dapat berlangsung dengan aman. Dimana hal ini selaras dengan tujuan dari konsep akad bai' assalam.

\section{KESIMPULAN}

Pelaksanaan Bai' As-Salam dalam kegiatan ekspor kopi pada sistem kontrak jual beli yang dilakukan oleh pihak CV. Oro Coffee pada dasarnya telah memenuhi rukun dan syaratsyarat Bai' As-Salam berdasarkan konsep dan ketentuan syariat Islam. Walaupun dari hasil wawancara yang dilakukan penulis bahwa transaksi Bai' As-Salam yang dilakukan telah memenuhi rukun dan syarat syarat tersebut tidak dinyatakan secara jelas namun sudah tersirat saat transaksi dilakukan karena adanya kepercayaan, kesepakatan dan kerelaan para pihak untuk melakukan transaksi.

Dengan terpenuhinya rukun dan syarat-syarat Bai' $A s$-Salam pada pelaksanaan Bai' $A s$ Salam dalam kegiatan ekspor, maka dalam hal ini penulis mengambil kesimpulan bahwa segala bentuk risiko yang terjadi pada kegiatan ekspor kopi apabila telah memenuhi syarat dan rukun maka Bai' As-Salam dalam perjanjian kontrak ekspor kopi yang dilakukan oleh CV. Oro Coffee dianggap sah.

\section{DAFTAR PUSTAKA}

Ad-Dimasyqi, Al-'Allamah Muhammad bin 'Abdurrahman. 2001. Fiqih Empat Mazhab. Bandung: Hasyimi Press.

Antonio, Muhammad Syafi'i. 2007. Bank Syari'ah dari Teori ke Praktik. Jakarta: Gema Insani.

Al Qalam: Jurnal Ilmiah Keagamaan dan Kemasyarakatan Vol. 16, No. 2

Maret - April 2022 
Ikram Pratama, Hardi Alunaza, Arifin Abdullah, Muhammad Iqbal : Analisis Kegiatan Ekspor Kopi Antara Kualitas Dengan Harga Dalam Perspektif Akad Bai’ As-Salam

M.S, Amir. 1999. Ekspor Impor Teori dan Penerapan. Jakarta: PT.Pustaka Binaan.

Rozalinda. 2010. Fiqih Ekonomi Syariah. Jakarta: Raja Grapindo Persada.

Semmawi, Ramli. 2010. "Urgensi Akad Dalam Hukum Ekonomi Islam.” Jurnal Al-Syir'ah 8 (2).

Sri Rejeki Hartono, Paramita Prananingtyas dan Fahimah. 2010. Kamus Hukum Ekonomi: 87.

Sugiyono. 2009. Metode Penelitian Bisnis (Pendekatan Kuantitatif, kualitatif, dan $R \& D$ ). Bandung: Alfabeta.

Tsalabi, Muhammad Mustofa. 1964. al-Madkhal Fi Ta'rif al-Fiqh al-Islam Wa Qawa'id al Milkiyyah Wa al-Uqudiyyah. Mathba"e ah Dar al-Ta"rif.

Zuhaili, Wahbah. 2011. Al-Fiqh al-Islami wa Adillatuh. Jakarta : Gema Insani.

Al Qalam: Jurnal Ilmiah Keagamaan dan Kemasyarakatan Vol. 16, No. 2

Maret - April 2022 